\title{
Partial purification and characterization of a bacteriocin produced by Enterococcus faecium 130 isolated from mozzarella cheese
}

\author{
Purificação parcial e caracterização da bacteriocina produzida por \\ Enterococcus faecium 130 isolado de mussarela
}

\author{
Fabrício Luiz TULINI ${ }^{1}$, Bruna Carrer GOMES ${ }^{1}$, Elaine Cristina Pereira DE MARTINIS ${ }^{1 *}$
}

\begin{abstract}
Lactic acid bacteria are important in foods as potential probiotics and also due to the ability to produce antimicrobial compounds that can contribute for biopreservation. In this work, the bacteriocin produced by the food isolate Enterococcus faecium 130 was partially purified and characterized. The compound was active against Gram-positive bacteria, including Listeria monocytogenes. It was produced after 4 days of storage at a broad temperature range $\left(4\right.$ to $37^{\circ} \mathrm{C}$ ); it was stable at $\mathrm{pH}$ ranging from 2 to 10 with no loss of activity after heating at $100{ }^{\circ} \mathrm{C}$ for 15 minutes. Bacteriocin was partially purified by the adsorption-desorption technique, and the analysis by sodium dodecyl sulfatepolyacrylamide gel electrophoresis (SDS-PAGE) showed a molecular mass of 3.5 to $6.5 \mathrm{kDa}$. These data encourage studies on application of this bacteriocin in food systems as an additional hurdle to microbial growth.

Keywords: Enterococcus faecium; bacteriocin; purification; SDS-PAGE; foods; Listeria monocytogenes.
\end{abstract}

\begin{abstract}
Resumo
Bactérias láticas são importantes em alimentos por apresentarem características probióticas e poderem ser empregadas como bioconservantes devido à capacidade de produzirem compostos antimicrobianos. No presente trabalho, a bacteriocina produzida por Enterococcus faecium 130 , isolado de alimentos, foi parcialmente purificada e caracterizada. O composto apresentou ação inibitória na multiplicação de bactérias Gram-positivas, incluindo Listeria monocytogenes. Foi produzida em uma ampla faixa de temperatura $\left(4\right.$ e $\left.37^{\circ} \mathrm{C}\right)$, estável em $\mathrm{pH}$ variando de 2 a 10 e não houve perda de atividade após aquecimento a $100{ }^{\circ} \mathrm{C}$ por 15 minutos. A purificação parcial da bacteriocina foi realizada pela técnica de adsorção-dessorção e o produto foi analisado por SDS-PAGE (sodium dodecyl sulfate-polyacrylamide gel electrophoresis), sendo determinada a massa molecular aproximada entre 3,5 e 6,5 kDa. Os resultados obtidos estimulam novos estudos sobre a aplicação da bacteriocina em alimentos como uma barreira adicional contra a contaminação microbiana.

Palavras-chave: Enterococcus faecium; bacteriocina; purificação; SDS-PAGE; alimentos; Listeria monocytogenes.
\end{abstract}

\section{Introduction}

Enterococci belong to group of the lactic acid bacteria (LAB) and have ambiguous significance in foods with both beneficial and detrimental aspects. They can extend shelf-life by the production of antimicrobials, synthesize flavor compounds, and contribute to health promotion as probiotic cultures. On the other hand, undesirable properties of enterococci have also been reported, such as indication of fecal contamination, presence of virulence factors, and multiple antibiotic resistance genes (ROSS; MORGAN; HILL, 2002). Many enterococci produce bacteriocins, defined as ribosomally synthesized peptides produced as a defense mechanism against closely related bacteria (OSCARIZ; PISABARRO, 2001). Different inhibition mechanisms of bacteriocins against target bacteria have been proposed, such as dissipation of proton motive force by pore formation, cell lyses, and interference with degradation and metabolism of macromolecules (DE MARTINIS; ALVES; FRANCO, 2002). Only nisin, a bacteriocin produced by Lactococcus lactis subsp. lactis, presents significant commercial application, and the wide use of bacteriocins in the food industry is still difficult due to regulatory aspects and lack of suitable technological methods to obtain large amounts of the peptides (CLEVELAND et al., 2001; DEEGAN et al., 2006).

Ammonium sulphate precipitation is the most commonly method used to purify proteins from culture broths, but it results in highly contaminated preparations which need to be dialyzed several times (WANG; LIU; CUI, 2007). An alternative for the selective purification of bacteriocins from culture broths is the adsorption-desorption process proposed by Yang, Johnson and Ray (1992) based on cationic properties of some bacteriocins at neutral $\mathrm{pH}$ promoting the adsorption to anionic surface of the bacterial cell membrane (OSCARIZ; PISABARRO, 2001).

Bacteriocin-producing enterococci have been isolated from different sources and several strains may produce class IIa bacteriocins, which are heat stable, cationic, hydrophobic, and low molecular weight peptides (GALVÉZ; LÓPEZ; ABRIOUEL, 2008, STROMPFOVÁ et al., 2006). There are also strains of enterococci that produce lantibiotic (class I), cyclic (class III),

Recebido para publicação em 2/3/2009

Aceito para publicação em 18/7/2009 (004083)

Faculdade de Ciências Farmacêuticas de Ribeirão Preto, Universidade de São Paulo - USP, Av. do Café, s/n, CEP 14040-903, Ribeirão Preto - SP, Brasil, E-mail: edemarti@usp.br

${ }^{*}$ A quem a correspondência deve ser enviada 
and large bacteriocins (class IV) with good stability at different $\mathrm{pH}$ values and broad antimicrobial spectrum (STROMPFOVÁ; LAUKOVÁ, 2007).

For application of enterococci in biopreservation, the strains have to be carefully studied, and it is highly desirable to obtain isolates from foods in which they intend to be used due to peptide stability and competitive advantage. It was found that bacteriocinogenic E. faecium 130 presents no pathogenic potential, demonstrated by absence of phenotypic virulence markers, virulence and antibiotic resistance genes (GOMES et al., 2008). In the present work, the bacteriocin of E. faecium 130 was further characterized aiming future food application.

\section{Materials and methods}

\subsection{Bacterial strains}

E. faecium 130 was previously isolated from mozzarella cheese (GOMES et al., 2008) and maintained at $-80^{\circ} \mathrm{C}$ in MRS broth (De Man, Rogosa, Sharpe, Oxoid, Basingstoke, United Kingdom) containing 20\% (v/v) glycerol. Working cultures were prepared in MRS broth at $37^{\circ} \mathrm{C}$ for 24 hours. L. monocytogenes ATCC 19115 was grown at $37^{\circ} \mathrm{C}$ for 24 hours in BHI broth (Brain Heart Infusion, Oxoid, UK), and it was used throughout the study as an indicator strain in bacteriocin production assays. The spectrum of inhibitory activity was determined with the strains listed in Table 1.

\subsection{Inhibitory spectrum of the bacteriocin produced by E. faecium 130}

For determination of inhibitory spectrum of the bacteriocin, according to Lewus, Kaiser and Montville (1991), E. faecium 130 was grown in MRS broth at $37^{\circ} \mathrm{C}$ for 24 hours, and $2 \mu \mathrm{L}$ of the broth culture were spotted on TSA-YE agar plates (Trypticase Soy Agar plus $0.6 \%$ of yeast extract, Oxoid, UK). After anaerobic incubation (Anaerogen, Oxoid, UK), to prevent hydrogen peroxide production, at $37^{\circ} \mathrm{C}$ for 24 hours, the bottom agar was covered with a $7 \mathrm{~mL}$-layer of soft BHI agar (BHI broth added $0.8 \%$ agar, Oxoid, UK) seeded with indicator strain (ca. $\left.10^{5}-10^{6} \mathrm{CFU} \cdot \mathrm{mL}^{-1}\right)$. The plates were further incubated under anaerobic condition for 24 hours and the results were obtained by measuring the radius of inhibition zones $(\mathrm{mm})$.

\subsection{Quantification of bacteriocin in different culture media}

Quantitative determination of bacteriocin activity was done by the critical dilution assay (MAYR-HARTING; HEDGES; BERKELEY, 1972). Briefly, neutralized filter-sterilized culture supernatants of E. faecium 130 grown in BHI, MRS or TSB-YE (Trypticase Soy Broth plus 0.6\% Yeast Extract, Oxoid, UK) were serially two-fold diluted with phosphate buffer $(10 \mathrm{mM}$, $\mathrm{pH}$ 7.0). Each dilution $(10 \mu \mathrm{L})$ was spotted on BHI agar plates previously overlaid with $7 \mathrm{~mL}$ of soft $\mathrm{BHI}$ agar inoculated with ca. $10^{5}-10^{6} \mathrm{CFU}$ of $L$. monocytogenes per $\mathrm{mL}$. The plates were incubated at $37^{\circ} \mathrm{C}$ for 24 hours and the results were expressed in arbitrary units per $\mathrm{mL}\left(\mathrm{AU} \cdot \mathrm{mL}^{-1}\right)$, defined as the reciprocal of the highest inhibitory dilution. Three independent experiments
Table 1. Strains and culture conditions used for evaluation of the spectrum of activity of the bacteriocin produced by Enterococcus faecium 130.

\begin{tabular}{|c|c|c|c|}
\hline Strain & $\begin{array}{l}\text { Culture } \\
\text { medium }\end{array}$ & $\begin{array}{l}\text { Incubation } \\
\text { temperature }\end{array}$ & $\begin{array}{l}\text { inhibition } \\
\text { halo }(\mathrm{mm})^{(5)}\end{array}$ \\
\hline Bacillus cereus ${ }^{(1)}$ & BHI & $37^{\circ} \mathrm{C}$ & 0 \\
\hline $\begin{array}{l}\text { Escherichia coli } \\
\text { CDC } 02 \mathrm{~A} .2 \mathrm{~B}^{(3)}\end{array}$ & BHI & $37^{\circ} \mathrm{C}$ & 0 \\
\hline $\begin{array}{l}\text { Carnobacterium } \\
\text { maltaromaticum } \mathrm{C}^{(4)}\end{array}$ & BHI & $37^{\circ} \mathrm{C}$ & 10 \\
\hline $\begin{array}{l}\text { Lactobacillus sakei } \\
\text { ATCC } 15521^{(2)}\end{array}$ & MRS & $25^{\circ} \mathrm{C}$ & 12 \\
\hline $\begin{array}{l}\text { Leuconostoc } \\
\text { mesenteroides } \mathrm{A} 13^{(4)}\end{array}$ & MRS & $25^{\circ} \mathrm{C}$ & 0 \\
\hline $\begin{array}{l}\text { Listeria monocytogenes } \\
\text { ATCC } 19115^{(2)}\end{array}$ & $\mathrm{BHI}$ & $37^{\circ} \mathrm{C}$ & 11 \\
\hline $\begin{array}{l}\text { Proteus mirabilis } \\
\text { CDC } 305^{(3)}\end{array}$ & $\mathrm{BHI}$ & $37^{\circ} \mathrm{C}$ & 0 \\
\hline $\begin{array}{l}\text { Staphylococcus aureus } \\
\text { ATCC } 29213^{(2)}\end{array}$ & $\mathrm{BHI}$ & $37^{\circ} \mathrm{C}$ & 0 \\
\hline
\end{tabular}

were performed in duplicate and the results presented are average of six replicates.

\subsection{Effect of incubation temperature on production of bacteriocin}

E. faecium 130 was grown in MRS broth for 24 hours at $37^{\circ} \mathrm{C}$, and $2 \mu \mathrm{L}$ of the culture were spotted on TSA-YE plates (Oxoid, UK), as described by De Martinis, Santarosa and Freitas (2003). Anaerobic incubation was carried out at 4, 10, 15, 30, and $37^{\circ} \mathrm{C}$ for 96 hours, and $37^{\circ} \mathrm{C}$ for 24 hours (positive control). The plates received a $7 \mathrm{~mL}$-layer of soft $\mathrm{BHI}$ agar seeded with ca. $10^{5}-10^{6} \mathrm{CFU}$ of $L$. monocytogenes per $\mathrm{mL}$, and the results were obtained by measuring the radius of inhibition zones $(\mathrm{mm})$. Three independent experiments were performed in duplicate and the results presented are the average of six replicates.

\subsection{Thermal and acid/base stability of the bacteriocin}

Neutralized and filter sterilized culture supernatant of E. faecium 130 from MRS broth $\left(37^{\circ} \mathrm{C}\right.$ for 24 hours) was assayed for thermal stability for 15 and 30 minutes, at 70, 80, 90, 100 and $121{ }^{\circ} \mathrm{C}$. To determine acid/base stability, the $\mathrm{pH}$ values of culture supernatants were adjusted to 2, 4, 7, and 10 and kept at $10{ }^{\circ} \mathrm{C}$ for 24 hours. For all conditions, bacteriocin activity was quantified as previously described (MAYR-HARTING; HEDGES; BERKELEY, 1972). Three independent experiments were performed in duplicate and the results presented are the average of six replicates.

\subsection{Determination of bactericidal or bacteriostatic activity}

The proteinaceous nature of the antagonistic substance produced by E. faecium 130 has been previously demonstrated by Gomes et al. (2008). In the present study, the bactericidal 
or bacteriostatic activity was determined as described by De Martinis, Santarosa and Freitas (2003), using E. faecium 130 supernatant in a critical dilution assay with $L$. monocytogenes as indicator strain. After 24 hours of incubation, $5 \mu \mathrm{L}$ of $10 \mathrm{mg} \cdot \mathrm{mL}^{-1}$ proteinase K solution (Sigma, St. Louis, MO, USA) were spotted next to each inhibition zone, and the plates were further incubated at $37^{\circ} \mathrm{C}$ and observed for presence or absence of growth of indicator after treatment with protease. The absence of listerial growth after the destruction of the inhibitor by protease indicated that bacterial cells had been killed by the peptide, whereas absence of inhibition zones after enzymatic treatment indicated a bacteriostatic mode of action. Three independent triplicate experiments were performed.

\subsection{Kinetics of growth and production of bacteriocin}

Growth kinetics of E. faecium 130 at $37^{\circ} \mathrm{C}$ was studied in MRS broth (Oxoid, UK) and monitored by plate counting on MRS agar (Oxoid, UK). Also, pH, optical density (O.D. ${ }_{600 \mathrm{~nm}}$ ) were measured and bacteriocin quantification was determined by the critical dilution method every two hours for up to 12 hours, plus a final measurement at 24 hours. Three independent triplicate were performed in duplicate and the results presented are the average of six replicates.

\subsection{Bacteriocin purification and molecular mass estimation}

The molecular mass of E. faecium 130 bacteriocin was estimated using a modification of the protocols proposed by Chen, Yanagida and Srionnual (2007) and Yang, Johnson and Ray (1992) to obtain a final product with fewer contaminants than bacteriocin preparations obtained from ammoniumsulphate precipitation. E. faecium 130 was cultivated in MRS broth at $37^{\circ} \mathrm{C}$ for 24 hours and the grown culture was used to inoculate two litters of MRS broth at $1 \%(\mathrm{v} / \mathrm{v})$. After incubation, the $\mathrm{pH}$ of the broth was adjusted to 6.0 (adsorption step), and the cells were harvested by centrifugation at $6,048 \mathrm{xg} / 20$ minutes $/ 4{ }^{\circ} \mathrm{C}$ (Sorvall RC 5C Plus, Newton, Connecticut, USA). The cell pellet was resuspended in $100 \mathrm{~mL}$ of $0.1 \mathrm{M} \mathrm{NaCl} / \mathrm{pH} 2.0$ solution (desorption step) and kept under agitation for 1 hour at $4{ }^{\circ} \mathrm{C}$. The pellet was removed by centrifugation $\left(10,080 \mathrm{xg} / 10\right.$ minutes $\left./ 4{ }^{\circ} \mathrm{C}\right)$ and the supernatant was dialyzed for 72 hours at $4{ }^{\circ} \mathrm{C}$ against water in cellulose ester membrane with exclusion limit of $1 \mathrm{kDa}$ (Spectra/Por ${ }^{\circledR}$ Biotech Cellulose Ester Dialysis Membrane, Spectrum, Rancho Dominguez, California, USA). After dialysis, the solution was freeze-dried (VirTis Lyophilizer, Gardner, New York, USA) and the protein concentration was measured by the Bradford method (1976). The purification product was analyzed by SDS-PAGE (Sodium dodecyl sulphate polycrylamide gel electrophoresis) with $16.5 \%$ separating gel and $4 \%$ stacking gel, at $10 \mathrm{~mA}$ for 4 hours. A pre-stained low-weight molecular mass marker was used with a range of 2.5 to $45 \mathrm{kDa}$ (Amersham Biosciences, Buckinghamshire, UK). Half of the gel was stained with a silver-staining kit (Amersham Biosciences), and the other half was used for biorevelation. For that, the gel was fixed with ethanol/acetic acid/water solution (4:1:3) for 30 minutes, washed with distillated water for 2 hours, transferred to the surface of one BHI agar plate
(Oxoid), and overlaid with BHI soft-agar (Oxoid) seeded with L. monocytogenes (ca. $10^{5}-10^{6} \mathrm{CFU} \cdot \mathrm{mL}^{-1}$ ). The overlaid gel was pre-incubated for 18 hours at $4{ }^{\circ} \mathrm{C}$, followed by incubation at $37^{\circ} \mathrm{C}$ for 24 hours.

\section{Results and discussion}

E. faecium 130 inhibited L. monocytogenes and some other Gram positive bacteria, but not the Staphylococcus aureus strain tested (Table 1). These results are partially in agreement with those reported by Ghrairi et al. (2008), who found that the bacteriocin produced by E. faecium MMT21 inhibited not only closely related LAB, but also L. monocytogenes and S. aureus. Different spectrum of inhibitory action may be obtained depending on the bacteriocin producing strain, the indicator strain, and also the method used for bacteriocin detection (LEWUS; MONTVILLE, 1991; DRIDER et al., 2006).

E. faecium 130 produced more bacteriocin in MRS broth $\left(6,400 \mathrm{AU} \cdot \mathrm{mL}^{-1}\right)$ in comparison to the production in TSB-YE and BHI broths $\left(3,200\right.$ and 800 AU.mL ${ }^{-1}$, respectively). A reduction of the bacteriocin production at $4,10,15$, and $30^{\circ} \mathrm{C}$ for 96 hours was observed when compared to the control incubated at $37^{\circ} \mathrm{C}$ (Figure 1). Based on these results, all other tests were conducted in MRS broth at $37^{\circ} \mathrm{C}$. Leroy and De Vuyst (2002) studied the production of bacteriocin by Enterococcus faecium RZS C5 under different temperatures and obtained similar results with less bacteriocin production below $35^{\circ} \mathrm{C}$; probably due to cellular environment regulation and growth related processes. The bacteriocin of E. faecium 130 retained at least $75 \%$ of its activity in MRS broth in the $\mathrm{pH}$ range of 2 to 10 when stored at $10^{\circ} \mathrm{C}$ for 24 hours (Table 2). It remained stable after 15 minutes at $100{ }^{\circ} \mathrm{C}$ and lost $50 \%$ of activity after treatment at $100^{\circ} \mathrm{C}$ for 30 minutes (Table 2). The thermal stability of the bacteriocin produced by E. faecium 130 was similar to that of E. faecium D081821, but it was more heat stable than the bacteriocin of E. faecium D081833 (CHEN; YANAGIDA; SRIONNUAL, 2007).

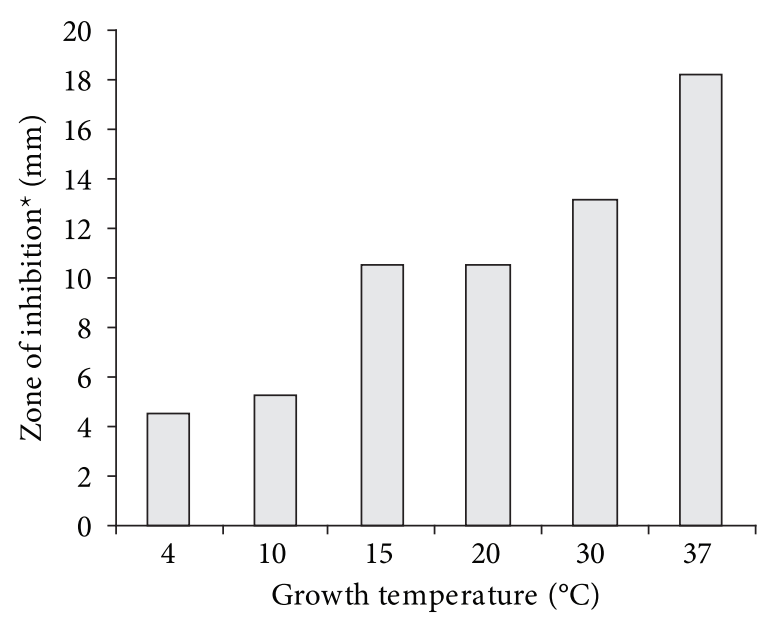

Figure 1. Production of bacteriocin by Enterococcus faecium 130 after incubation for 4 days at different temperatures quantified by agar antagonism assay using L. monocytogenes ATCC 19115 as indicator. ${ }^{\star}$ Inhibition was measured from the border of the colony up to the end of the inhibition halo. 


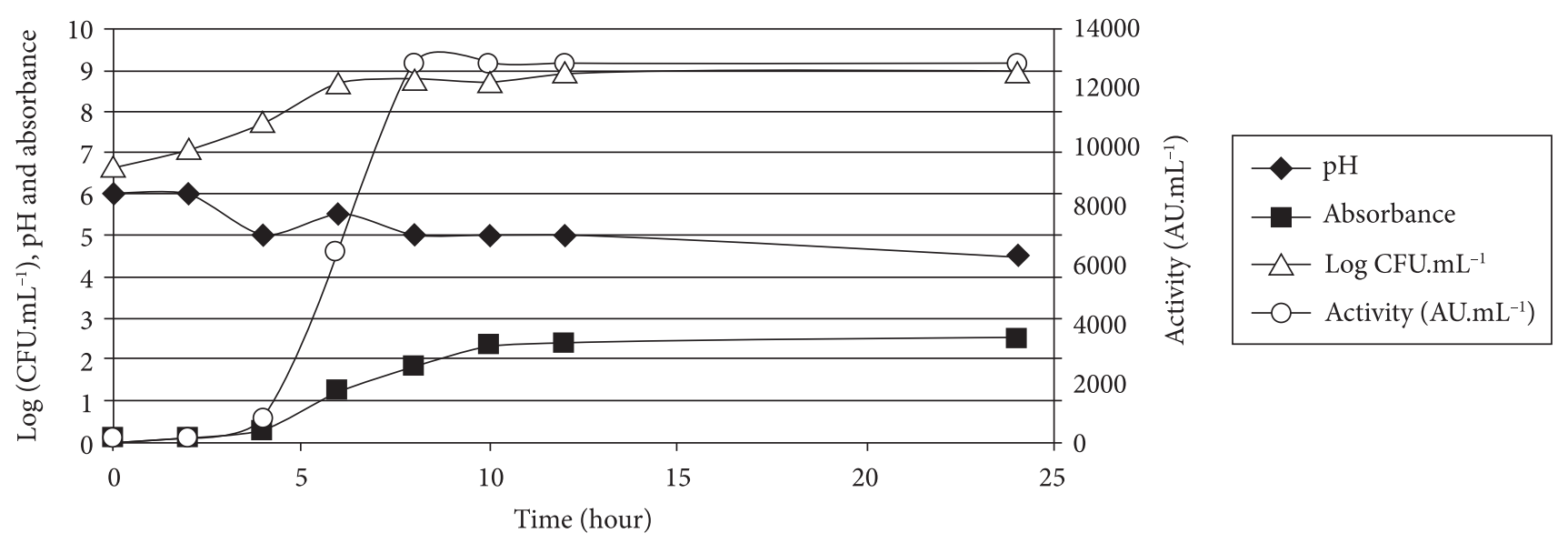

Figure 2. Growth kinetics and bacteriocin production by Enterococcus faecium 130 in MRS broth at $37^{\circ} \mathrm{C}$.
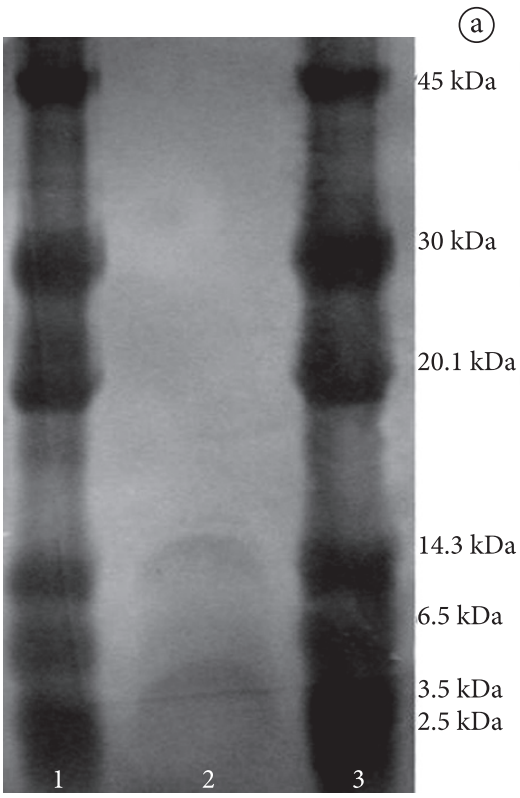

Figure 3. Photographies of SDS-PAGE analysis with the extract obtained after partial purification of the bacteriocin produced by E. faecium 130. a) Silver stained gel. Lane 1 and 3: pre-stained low-range molecular marker; lane 2: bacteriocin extract; b) Gel prepared with bacteriocin extract revealed with biomarker L. monocytogenes. The pre-stained molecular marker indicates the molecular weight range.

Bactericidal mode of action was observed at 3,200 AU.mL ${ }^{-1}$, but only bacteriostatic activity was detected at lower concentrations (200 AU.mL $L^{-1}$ ) indicating that low concentrations may favor the emergence of bacteriocin-resistant cells. According to Nagmouchi et al. (2007), the acquirement of resistance by L. monocytogenes to class I and class IIa bacteriocins may lead to decreased bacteriocin sensitivity.

The maximum population of E. faecium 130 in MRS broth at $37^{\circ} \mathrm{C}$ was reached after 6-7 hours of incubation (Figure 2), and the production of bacteriocin was first detected after 2 hours of incubation (100 AU.mL ${ }^{-1}$ ), whereas the peak of bacteriocin
Table 2. Effect of thermal treatment and $\mathrm{pH}$ in the stability of the bacteriocin produced by Enterococcus faecium $130^{*}$.

\begin{tabular}{|c|c|c|}
\hline & Treatment & Bacteriocin activity $\left(\mathrm{AU} \cdot \mathrm{mL}^{-1}\right)$ \\
\hline \multirow[t]{9}{*}{ Heat } & $70^{\circ} \mathrm{C}$ for 15 minutes & 6400 \\
\hline & $70^{\circ} \mathrm{C}$ for 30 minutes & 6400 \\
\hline & $80^{\circ} \mathrm{C}$ for 15 minutes & 6400 \\
\hline & $80^{\circ} \mathrm{C}$ for 30 minutes & 6400 \\
\hline & $90^{\circ} \mathrm{C}$ for 15 minutes & 6400 \\
\hline & $90^{\circ} \mathrm{C}$ for 30 minutes & 6400 \\
\hline & $100^{\circ} \mathrm{C}$ for 15 minutes & 6400 \\
\hline & $100{ }^{\circ} \mathrm{C}$ for 30 minutes & 3200 \\
\hline & $\begin{array}{l}121^{\circ} \mathrm{C} \text { for } 15 \text { minutes } \\
\text { (autoclave) }\end{array}$ & 0 \\
\hline \multirow[t]{4}{*}{$\mathrm{pH}$} & 2 & 5600 \\
\hline & 4 & 4800 \\
\hline & 7 & 6400 \\
\hline & 10 & 6400 \\
\hline
\end{tabular}

${ }^{*}$ L. monocytogenes ATCC 19115 was used as indicator strain.

production was observed at 8 hours $\left(12,800 \mathrm{AU} \cdot \mathrm{mL}^{-1}\right)$, during the exponential growth phase.

The adsorption-desorption technique used in this study to partially purify the bacteriocin of E. faecium 130 from MRS broth yielded $18.9 \mathrm{mg}$ of dry powder with a protein content of $0.00746 \mathrm{mg}$ (specific activity $26,809 \mathrm{AU}$ of bacteriocin per mg of protein). Some bacteriocin activity was lost in the supernatant, probably due to the saturation of adsorbing sites on the bacterial cells. The bacteriocin of E. faecium 130 obtained by the adsorption-desorption technique was resolved by SDS-PAGE, and the peptides bands were visualized between 3.5 and $14.3 \mathrm{kDa}$ after silver staining (Figure 3). SDS-PAGE gels were also revealed with bioindicator $L$. monocytogenes, and an inhibition zone between 3.5 and $6.5 \mathrm{kDa}$ was detected. These results are similar to those found by Chen, Yanagida and Srionnual (2007) for bacteriocin like substances from $E$. faecium D081821 and D081833, which were ca. $3 \mathrm{kDa}$ in size. 


\section{Conclusions}

The results of molecular weight, heat stability, and peptide stability at diferent $\mathrm{pH}$ values obtained for E. faecium 130, indicate that it produces a bacteriocin that probably belongs to the class IIa. Further studies on food systems and more purification steps are encouraged for the practical application of the bacteriocin of E. faecium 130 as a food preservative.

\section{Acknowledgements}

Authors are grateful for the financial support provided by FAPESP (The State of São Paulo Research Foundation, Brazil, process \# 03/11986-2) and CNPq (National Council for Scientific and Technological Development, Brazil, process \# 501802-2007-0).

\section{References}

BRADFORD, M. M. A rapid and sensitive method for the quantitation of microgram quantities of protein utilizing the principle of proteindye binding. Analytical Biochemistry, v. 72, p. 248-254, 1976.

CHEN, Y. S.; YANAGIDA, F.; SRIONNUAL, S. Characteristics of bacteriocin-like inhibitory substances from dochi-isolated Enterococcus faecium D081821 and D081833. Letters in Applied Microbiology, v. 44, p. 320-325, 2007.

CLEVELAND, J. et al. Bacteriocins: safe natural antimicrobials for food preservation. International Journal of Food Microbiology, v. 71, p. 1-20, 2001.

DE MARTinis, E. C. P.; AlveS, V. F.; FRANCO, B. D. G. M. Fundamentals and perspectives for the use of bacteriocins produced by lactic acid bacteria in meat products. Food Reviews International, v. 18, n. 2-3, p. 191-208, 2002.

DE MARTINiS, E. C. P.; SANTAROSA, P. R.; FREITAS, F. Z. Caracterização preliminar de bacteriocinas produzidas por seis cepas de bactérias láticas isoladas de produtos cárneos embalados a vácuo. Ciência e Tecnologia dos Alimentos, v. 23, p. 195-199, 2003.

DEEGAN, L. H. et al. Bacteriocins: Biological tools for bio-preservation. International Dairy Journal, v. 16, p. 1058-1071, 2006.

DRIDER, D. et al. The continuing story of class IIa bacteriocins. Microbiology and Molecular Biology Reviews, v. 70, p. 564-582, 2006.

GALVÉZ, A.; LÓPEZ, R. L.; ABRIOUEL, H. Application of bacteriocins in the control of food-borne pathogenic and spoilage bacteria. Critical Reviews in Biotechnology, v. 28, p. 125-152, 2008.
GHRAIRI, T. et al. Purification and characterisation of bacteriocins produced by Enterococcus faecium from Tunisian rigouta cheese. Food Control, v. 19, p. 162-169, 2008.

GOMES, B. C. et al. Prevalence and characterization of Enterococcus spp. isolated from Brazilian foods. Food Microbiology, v. 25, n. 5, p. 668-675, 2008.

LEWUS, C. B.; KAISER, A.; MONTVILLE, T. J. Inhibition of foodborne bacterial pathogens by bacteriocins from lactic acid bacteria isolated from meat. Applied and Environmental Microbiology, v. 57 , p. 1683-1688, 1991.

LEWUS, C. B.; MONTVILLE, T. J. Detection of bacteriocins produced by lactic acid bacteria. Journal of Microbiological Methods, v. 13, p. 145-150, 1991.

LEROY, F; DE VUYST, L. Bacteriocin production by Enterococcus faecium RZS C5 is cell density limited and occurs in the very early growth phase. International Journal of Food Microbiology, v. 72, p. 155-164, 2002.

MAYR-HARTING, A.; HEDGES, A. J.; BERKELEY, R. C. W. Methods for studying bacteriocins. In: NORRIS, J. R.; RIBBONS, D. W. (Eds.) Methods in Microbiology. New York: Academic Press, 1972. v. 7a, p. 313-342.

NAGMOUCHI, K. et al. Class I/class IIa bacteriocin cross-resistance phenomenon in Listeria monocytogenes. Food Microbiology, v. 24, p. 718-727, 2007.

OSCARIZ, J. C.; PISABARRO, A. G. Classification and mode of action of membrane-active bacteriocins produced by gram-positive bacteria. International Microbiology, v. 4, p. 13-19, 2001.

ROSS, R. P.; MORGAN, S.; HILL, C. Preservation and fermentation: past, present and future. International Journal of Food Microbiology, v. 79, p. 3-16, 2002.

STROMPFOVÁ, V. et al. Enterococcus faecium EK13 - an enterocin A producing strain with probiotic character and its effect in piglets. Anaerobe, v. 12, p. 242-248, 2006.

STROMPFOVÁ, V.; LAUKOVÁ, A. In vitro study on bacteriocin production of Enterococci associated with chickens. Anaerobe, v. 13, p. 228-237, 2007.

WANG, W.; LIU, Q.; CUI, H. Rapid desalting and protein recovery with phenol after ammonium sulphate fractionation. Electrophoresis, v. 28, p. 1-3, 2007.

YANG, R.; JOHNSON, M. C.; RAY, B. Novel method to extract large amount of bacteriocins from lactic acid bacteria. Applied and Environmental Microbiology, v. 58, p. 3335-3359, 1992. 